\title{
Sedoanalgesia modality during laser photocoagulation for retinopathy of prematurity: Intraoperative complications and early postoperative follow-up
}

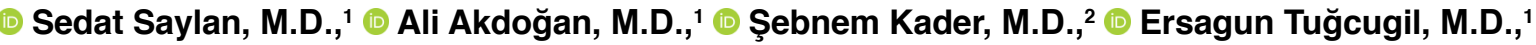 \\ (1) Ahmet Beşir, M.D., ${ }^{1}$ ๑ Mehmet Kola, M.D., ${ }^{3}$ ๑ Yakup Aslan, M.D. ${ }^{2}$
}

\begin{abstract}
1Department of Anesthesiology, Karadeniz Technical University Faculty of Medicine, Trabzon-Turkey ${ }^{2}$ Department of Neonatology, Karadeniz Technical University Faculty of Medicine, Trabzon-Turkey ${ }^{3}$ Department of Ophtalmology, Karadeniz Technical University Faculty of Medicine, Trabzon-Turkey
\end{abstract}

\begin{abstract}
BACKGROUND: Laser photocoagulation (LPC) is a surgical procedure used in the treatment of premature retinopathy that may cause retinal detachment and blindness if not diagnosed and treated early. The anesthesia method used in LPC varies from sedoanalgesia to general anesthesia and airway management varies from spontaneous ventilation to endotracheal intubation. In this study, we aimed to evaluate the effectiveness of sedoanalgesia applications and this anesthesia procedure concerning intraoperative and postoperative complications by avoiding intubation and mechanical ventilation in premature infants with a fragile population.
\end{abstract}

METHODS: This retrospective study included 89 patients who underwent laser photocoagulation under anesthesia for premature retinopathy. Patients' demographic characteristics, preoperative risk factors, anesthesia technique, especially airway management, changes in ventilation status during surgery, intraoperative complications, postoperative complications, and intensive care follow-up, were recorded and analyzed statistically.

RESULTS: Two of the 89 patients who underwent laser photocoagulation were excluded from this study because they were followed up intubated. The number of patients who received mask ventilation due to intraoperative complications was 12 (I3.8\%). The mean operation time was $36.2 \pm 10.1$ minutes. In $86.2 \%(n=75)$ of the patients, the surgical procedure was completed with sedoanalgesia while maintaining spontaneous ventilation.

CONCLUSION: Sedoanalgesia application during the surgical intervention of patients with Retinopathy of Prematurity (ROP) requiring early diagnosis and emergency treatment will minimize intraoperative and postoperative complications. We believe that sedoanalgesia as an anesthetic method can be applied as an effective alternative method while preserving spontaneous ventilation.

Keywords: Laser photocoagulation; retinopathy of prematurity; sedoanalgesia.

\section{INTRODUCTION}

Retinopathy of Prematurity (ROP) is a retinal disease that arises from abnormal proliferation of retinal vessels. ROP may cause retinal detachment and blindness if not detected early or left untreated. ROP is a major and preventable clinical problem worldwide leading to blindness in childhood. ${ }^{[1,2]}$
Epidemiological studies have identified prematurity and low birth weight as the most important risk factors for the development of ROP. Other identified risk factors include hyperoxia, hypoxia, mechanical ventilation, sepsis, intraventricular hemorrhage, blood transfusions, parenteral nutrition, pulmonary insufficiency and patent ductus arteriosus. ${ }^{[3,4]}$

Cite this article as: Saylan S, Akdoğan A, Kader Ş, Tuğcugil E, Beşir A, Kola M, et al. Sedoanalgesia modality during laser photocoagulation for retinopathy of prematurity: intraoperative complications and early postoperative follow-up. Ulus Travma Acil Cerrahi Derg 2020;26:754-759.

Address for correspondence: Sedat Saylan, M.D.

Karadeniz Teknik Üniversitesi Tıp Fakültesi, Anesteziyoloji ve Reanimasyon Anabilim Dalı, Trabzon, Turkey

Tel: +90 462 - 3775000 E-mail: sedatsaylan@yahoo.com

Ulus Travma Acil Cerrahi Derg 2020;26(5):754-759 DOI: 10.14744/tjtes.2020.62378 Submitted: 23.10.2019 Accepted: 29.05.2020 Online: 09.09.2020

Copyright 2020 Turkish Association of Trauma and Emergency Surgery 
Recent advances in neonatal care and the increase in neonatal intensive care units (NICUs) have decreased the mortality of the premature and low birth weight infants and increased the incidence of the ROP.

Laser photocoagulation therapy (LPT) is a surgical procedure to prevent the progression of ROP to visual impairment or blindness. ${ }^{[5]}$ The anesthesia method used in LPT varies from sedoanalgesia to general anesthesia, and airway management varies from spontaneous ventilation to endotracheal intubation. ${ }^{[6]}$ The low birth weight of the newborns who will be treated for ROP, the presence of additional systemic diseases, and more frequent peroperative and postoperative complications make the anesthesia method and follow-up more important.

The primary objective of this study was to evaluate the results of sedoanalgesia as an anesthesia protocol during laser photocoagulation in ROP. The secondary aim was to investigate the effects of anesthesia method on follow-up results and discharge in the neonatal intensive care unit concerning intraoperative and postoperative complications. The clinical data of these newborns were retrospectively analyzed to evaluate the effectiveness of the sedoanalgesia procedure to avoid intubation and mechanical ventilation.

\section{MATERIALS AND METHODS}

Upon the approval of the local ethics committee of the state university, this study was started. This study included 89 cases that underwent laser photocoagulation under anesthesia for ROP between 2012 and 2017. Two of the patients were excluded from this study due to intubation and mechanical ventilation requirement. Patient files, anesthesia record forms, early postoperative and NICU follow-up procedures were evaluated retrospectively to evaluate the effectiveness of anesthesia procedure in our clinic.

Five-point scale was used to evaluate the babies according to their birth week and birth weight, and infants were classified as follows:

\begin{tabular}{llll} 
Birth week & \multicolumn{2}{c}{ Birth weight } \\
Immature <24 weeks: & $0<500$ (abort) & 0 \\
Severe <28 weeks: & I & $<750$ g ILBW (incredibly low birth weight) & I \\
Medium 28-32 weeks: & 2 & $1000-750$ g ELBW (extremely low birth weight) & 2 \\
Light 32-36 weeks: & 3 & $1500-1000$ g VLBW (very low birth weight) & 3 \\
At the limits 37 weeks: & 4 & $2500-1500$ g LBW(low birth weight) & 4
\end{tabular}

Preoperative anesthesia recommendations were followed and the evaluations and suggestions of the pediatric minor physicians were obtained. Transport of the patients from the neonatal intensive care unit to the operating room was performed using mechanical ventilator transport incubator, and heat-pulse, pulse-oximeter monitoring was performed by a pediatric physician.
In this study, 2.5\% phenylephrine hydrochloride and $0.5 \%$ tropicamide were applied to all patients half an hour before the procedure for pupillary dilatation. In addition, $0.5 \%$ proparacaine hydrochloride drops were used for all the patients as local anesthesia five minutes before the operation.

Electrocardiogram (ECG), peripheral oxygen saturation, blood pressure and body temperature measurements were performed. Gender, gestational age, postconceptional age, birth weight, weight during treatment, laser photocoagulation week and preoperative risk factors (low birth weight, respiratory distress syndrome, bronchopulmonary dysplasia, oxygen therapy, CPAP, mechanical ventilation, apnea, sepsis and cardiac anomaly) were recorded. Anesthesia technique was examined especially for airway management, changes in ventilation status during surgery and intraoperative complications (bronchospasm, desaturation, apnea, convulsion and bradycardia), operation time and other drugs used. Patients admitted to the postoperative recovery unit were allowed to be transferred to the NICU when the Post-Anesthesia Recovery Scoring System (PARSS) score was 6 or higher. ${ }^{[7]}$ All patients were transported postoperatively in an incubator and monitored by a pediatric physician. Postoperative follow-up was monitorized in the NICU for 24 hours. Postoperative complications (bronchospasm, desaturation, apnea, convulsion and bradycardia) were recorded.

\section{Sedoanalgesia Procedure}

After noninvasive monitoring of the patients brought to the operating table under the incubator, midazolam $0.1 \mathrm{mg} / \mathrm{kg}$ and ketamine $1 \mathrm{mg} / \mathrm{kg}$ were administered intravenously to all patients for sedoanalgesia, and ketamine $0.25 \mathrm{mg} / \mathrm{kg} / \mathrm{h}$ infusion was administered for maintenance. All babies were also administered atropine to minimize the salivation effect seen with ketamine and to decrease the oculocardiac reflex.

The degree of sedation was monitored with a neonatal infant pain scale (NIPS). Surgical procedure was allowed when NIPS $\leq I$ and no response to eye speculum placement. In case of prolonged apnea or desaturation, patients were ventilated via a mask.

\section{Statistical Methods}

The data were analyzed using Statistical Package for Social Sciences (SPSS Inc., Chicago, IL) Version 23.0. Normal distribution of the numerical variables was evaluated with the Kolmogorov-Smirnov test. Descriptive statistics were made. Numerical variables were given as mean \pm standard deviation (SD) and median (IQR: $25 \%-75 \%$ ) and categorical variables as number (n) and percentage (\%). Statistical significance level was taken as $\mathrm{p}<0.05$.

\section{RESULTS}

Demographic data, preoperative characteristics and risk factors of the patients are given in Table I. The anesthesia man- 
Table I. Demographic data and preoperative characteristics

\section{Gender, $\mathrm{n}(\%)$ \\ Male}

Female

American Society of Anesthesiologists, $n$ (\%)

II

III

Gestational age (week), (mean \pm SD)

$27.94 \pm 2.95$

Birth weight (gr), (mean \pm SD)

I $102.4 \pm 404.4$

Postconceptional age (week), (mean \pm SD)

$39.65 \pm 4.6$

Body weight (gr) [Median (IQR: 25\%-75\%)]

2600 (2100-2875)

Laser week (mean \pm SD)

II $.67 \pm 4.69$

Multiple pregnancies, $\mathrm{n}(\%)$

15 (16.9)

Definition of baby by birth weight, $n$ (\%)

0

$13(14.6)$

29 (32.6)

34 (38.2)

II (12.4)

Definition of the baby by birth week, $n$ (\%)

0

51 (57.3)

$23(25.8)$

$9(10.1)$

I (I.I)

Preoperative risk factors, $\mathrm{n}$ (\%)

Low birth weight

87 (97.8)

Mechanical ventilation

$52(58.4)$

Continuous positive airway pressure

$36(40.4)$

Sepsis

Anemia, transfusion

$24(27.0)$

$\mathrm{O}_{2}$ treatment

$20(22.5)$

Respiratory distress syndrome

Cardiac anomaly

Epilepsy

10 (1I.2)

Hypothyroidism

7 (7.9)

Bronchopulmonary dysplasia

$6(6.7)$

$6(6.7)$

$6(6.7)$

3 (3.4)

2 (2.2)

$2(2.2)$

I (I.I)

agement, mean operation time and intraoperative complications of the cases are shown in Table 2.

Table 2. Anesthesia management and intraoperative complications

\begin{tabular}{lc} 
Type of anesthesia, $\mathrm{n}(\%)$ & \\
Sedoanalgesia (spontaneous breathing) & $75(86.2)$ \\
Sedoanalgesia (mask ventilation) & $12(13.8)$ \\
Operation time (min), mean \pm SD & $36.24 \pm 10.19$ \\
Intraoperative complications, $\mathrm{n}(\%)$ & \\
Bronchospasm & $3(2.3)$ \\
Desaturation & $12(13.8)$ \\
Apnea & $8(9.2)$ \\
Convulsions & $1(1.1)$ \\
Bradycardia & $10(11.5)$ \\
\hline
\end{tabular}

Table 3. Postoperative complications and intensive care follow-up $(n=87)$

\begin{tabular}{|c|c|c|}
\hline & $\mathbf{n}$ & $\%$ \\
\hline New antiepileptic therapy & 2 & 2.3 \\
\hline \multicolumn{3}{|l|}{ Oxygen supply } \\
\hline In incubator & 7 & 8 \\
\hline With Hood & 2 & 2.3 \\
\hline Nasal-SIMV & 3 & 3.6 \\
\hline Endotracheal-SIMV & 4 & 4.6 \\
\hline Emerging respiratory failure and $\mathrm{mv}$ requirement & 7 & 8.0 \\
\hline Respiratory stimulant (caffeine) requirement & 4 & 4.6 \\
\hline \multicolumn{3}{|l|}{ Monitoring time in mechanical ventilator (days) } \\
\hline I & 6 & 6.9 \\
\hline 2 & 1 & I.I \\
\hline
\end{tabular}

Two of the 89 patients who underwent laser photocoagulation were excluded from this study because they were followed up intubated. Eight of the 87 patients included in this study had apnea, three had bronchospasm, and one patient had convulsion during operation and these desaturated patients underwent mask ventilation (Fig. I). Surgical procedure was completed smoothly in patients whose spontaneous respiration returned after mask ventilation and peripheral oxygen saturation was within normal limits. Ten patients had bradycardia and surgery was interrupted, and tactile stimulation and atropine were used to achieve normal heart rate in all patients. In $86.2 \%$ $(n=75)$ of the patients, the surgical procedure was completed with sedoanalgesia while maintaining spontaneous ventilation.

In the postoperative NICU follow-up, two patients developed convulsion and started antiepileptic treatment. The history of these patients included risk factors, such as low birth weight, respiratory distress syndrome and epilepsy. Sixteen patients who developed apnea and bronchospasm needed oxygen support, and seven of these patients received mechanical ventila- 


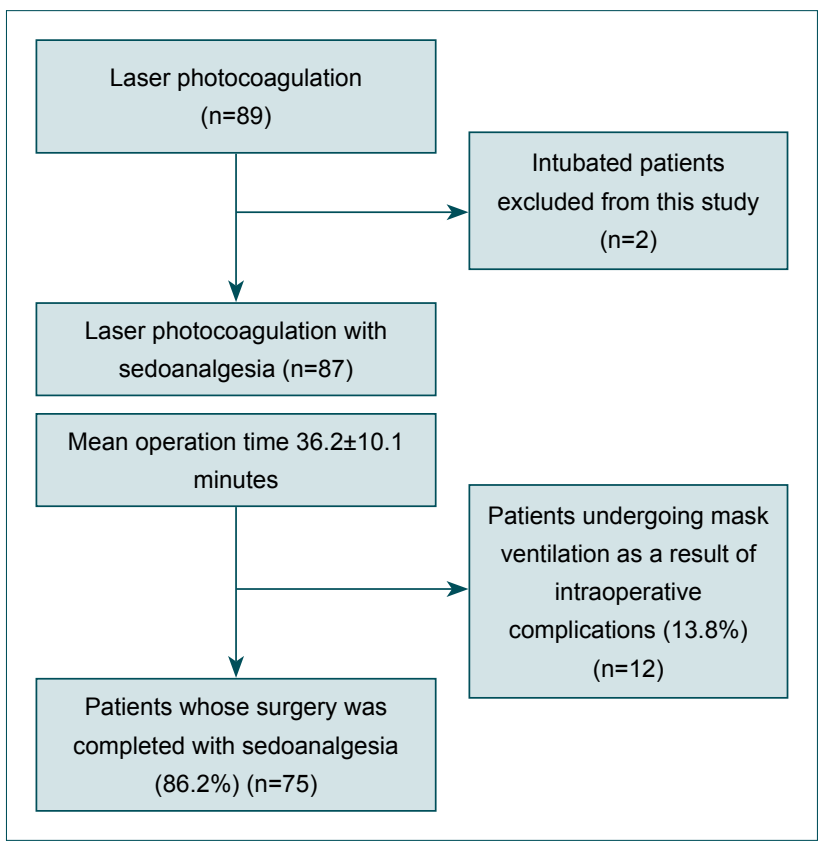

Figure 1. Study flow diagram.

tion. Patients who had mechanical ventilation for a maximum of two days did not develop any problems during the subsequent follow-up (Table 3).

\section{DISCUSSION}

ROP is a disease that needs early diagnosis and treatment. ${ }^{[8]}$ Newborns and premature babies perceive pain and produce a stress response to painful stimuli. ${ }^{[9]}$ In addition, the oculocardiac reflex is well developed in infants, and they are more susceptible to apnea attacks and bradycardia with increased cardiorespiratory instability. ${ }^{[10]}$ Therefore, anesthesia support is required for ROP treatment with laser. However, there is still no consensus on the best anesthetic approach to use. ${ }^{[6]}$ Previous studies have examined the use of topical anesthetics, general anesthetics, sedation and analgesia combinations during laser photocoagulation for ROP treatment. Haigh et al. ${ }^{\left[{ }^{\prime \prime}\right]}$ found that the incidence of cardiovascular and respiratory complications was significantly increased with the use of topical anesthesia, but the performance of the procedure under general anesthesia or sedation/analgesia was comparable. We applied sedoanalgesia to all of our patients, but at the same time, we used eye drops containing local anesthetics five minutes before the operation.

Piersigili et al. ${ }^{[12]}$ demonstrated that fentanyl analgesia and propofol sedation were effective in this short-term surgery and had no side effects, thus forming the basis of a randomized trial to evaluate propofol safety. They stated that their aim was to avoid intubation in the neonatal patient group, but they used a laryngeal mask for airway safety.

Lyon et al. ${ }^{[3]}$ stated that the use of ketamine sedation provides satisfactory conditions for the treatment of ROP, thus preventing complications related to general anesthesia in infants with many medical problems. They recommended the use of ketamine and other sedative techniques in the treatment of the ROP. We used ketamine in our unit. Ketamine is a short-acting 'dissociative' anesthetic with a strong analgesic effect lasting longer than the anesthesia period, and this analgesic effect occurs even at subanesthetic doses. ${ }^{[14]}$

Ketamine increases airway tone and thus maintains airway patency and respiratory function, and some studies suggest mild respiratory depression, but this has not been shown in other studies. ${ }^{[15]}$ We use low doses of midazolam to prevent ketamine-induced dissociative effects. We also use atropine in our clinic to prevent the increase of ketamine-induced salivation and to alleviate the oculocardiac reflex.

Ketamine is still the preferred drug in pediatric anesthesia because of its bronchodilator effect, protection of laryngeal, pharyngeal reflexes and minimal central respiratory effect. Meta-analysis of 32 studies on ketamine in sedoanalgesia demonstrated the incidence of apnea in $0.8 \%$ and laryngospasm in $0.3 \%$ of the patients. ${ }^{[16]}$

In premature newborns, general anesthesia may be associated with a high risk of morbidity, especially when intraventricular hemorrhage, patent ductus arteriosus (PDA), necrotizing enterocolitis (NEC), history of mechanical ventilation or bronchopulmonary dysplasia (BPD) are present. ${ }^{[17]}$

The presence of additional systemic diseases, as well as low birth weight, increases the risk in general anesthesia applications in premature infants. The use of invasive airway devices in this group of patients with a high rate of pulmonary disease in history paves the way for serious complications. Manipulation of the endotracheal tube may cause airway edema, bronchospasm, and laryngospasm in the postoperative period. ${ }^{[18]}$

Ulgey et al. compared the effects of general anesthesia and sedoanalgesia on postoperative mechanical ventilation for ROP. They stated that the use of deep sedation in premature infants who underwent ROP surgery reduced the need for postoperative mechanical ventilation compared to general anesthesia. ${ }^{[19]}$

Sixteen of our patients required postoperative oxygen supplementation, and only four of these patients underwent mechanical ventilation with endotracheal intubation. Invasive (4.6\%) and noninvasive (3.6\%) MV treatment was applied to seven patients who developed apnea and bronchospasm in the NICU. All of these patients had other preoperative risk factors, especially low birth weight. As a result, some infants who recently stopped care and mechanical ventilation required post-operative mechanical ventilation. Patients who received mechanical ventilation support for a maximum of two days were then discharged without any problems. Based on the available data, postoperative complications were not 
associated with ketamine. The incidence of apnea in premature babies is $20-30 \%$ and the frequency of apnea after general anesthesia increases up to $30 \%$. Especially low birth weight, low postconceptional age and endotracheal intubation increase the incidence of postoperative apnea. ${ }^{[20]}$ Thus, sedoanalgesia with close monitorized follow-up will provide hemodynamic stability and surgical comfort while avoiding intubation. ${ }^{[21]}$

Yavaşcaoğlu et al. ${ }^{[22]}$ stated that monitoring babies in the first 24 hours in the intensive care unit provided appropriate care to reduce postoperative complications. We provide the NICU transportation of all our patients in a standard, monitorized incubator with appropriate temperature in the company of pediatric doctors. In addition, all our patients are followed up in the postoperative NICU for 24 hours.

This study is limited to the anesthetic procedures applied in our hospital. The anesthetic approaches used in various centers in our country can be evaluated for the treatment of the ROP in future studies. In the light of these studies, a consensus can be established for the anesthesia method or methods used in the treatment of patients with ROP. In addition, this study does not compare sedoanalgesia with general anesthesia for patients with ROP. Therefore, it is not an alternative to general anesthesia.

As a result, sedoanalgesia application during the surgical intervention of the patients with ROP requiring early diagnosis and emergency treatment will minimize intraoperative and postoperative complications.

Ethics Committee Approval: Approved by the local ethics committee.

Peer-review: Internally peer-reviewed.

Authorship Contributions: Concept: S.S.; Design: S.S., A.A., S..K.; Supervision: E.T., A.B., M.K., Y.A.; Materials: A.A., Ş.K.; Data: S.S., A.A., Ş.K.; Analysis: S.S., A.A; Literature search: S.S., S..K., M.K.; Writing: S.S.; Critical revision: E.T., A.B., M.K., Y.A.

\section{Conflict of Interest: None declared.}

Financial Disclosure: The authors declared that this study has received no financial support.

\section{REFERENCES}

1. Zin A, Gole GA. Retinopathy of prematurity-incidence today. Clin Perinatol 2013;40:185-200 [CrossRef]

2. Gilbert C, Muhit M. Twenty years of childhood blindness: what have we learnt?. Community Eye Health 2008;21:46-7.

3. Owen LA, Morrison MA, Hoffman RO, Yoder BA, DeAngelis MM. Retinopathy of prematurity: A comprehensive risk analysis for prevention and prediction of disease. PLoS One 2017;12:e0171467 [CrossRef]

4. Karna P, Muttineni J, Angell L, Karmaus W. Retinopathy of prematurity and risk factors: a prospective cohort stud. BMC Pediatr 2005;5:18.

5. Allegaert K, Van de Velde M, Casteels I, Naulaers G, Vanhole C, Devlieger $\mathrm{H}$. Cryotherapy for threshold retinopathy: perioperative management in a single center. Am J Perinatol 2003;20:219-2థ. [CrossRef]

6. Chen SD, Sundaram V, Wilkinson A, Patel CK. Variation in anaesthesia for the laser treatment of retinopathy of prematurity--a survey of ophthalmologists in the UK. Eye (Lond) 2007;21:1033-6 [CrossRef]

7. Steward DJ. A simplified scoring system for the post-operative recovery room. Can Anaesth Soc J 1975;22:111-3 [CrossRef]

8. Early Treatment For Retinopathy Of Prematurity Cooperative Group. Revised indications for the treatment of retinopathy of prematurity: results of the early treatment for retinopathy of prematurity randomized trial. Arch Ophthalmol 2003;121:1684-94 [CrossRef]

9. Anand KJ, Hickey PR. Pain and its effects in the human neonate and fetus. N Engl J Med 1987;317:1321-9 [CrossRef]

10. Clarke WN, Hodges E, Noel LP, Roberts D, Coneys M. The oculocardiac reflex during ophthalmoscopy in premature infants. Am J Ophthalmol 1985;99:649-51. [CrossRef]

11. Haigh PM, Chiswick ML, O'Donoghue EP. Retinopathy of prematurity: systemic complications associated with different anaesthetic techniques at treatment. Br J Ophthalmol 1997;81:283- [CrossRef]

12. Piersigilli F, Di Pede A, Catena G, Lozzi S, Auriti C, Bersani I et al. Propofol and fentanyl sedation for laser treatment of retinopathy of prematurity to avoid intubation.J Matern Fetal Neonatal Med 2019;32:517-21.

13. Lyon F, Dabbs T, O'Meara M. Ketamine sedation during the treatment of retinopathy of prematurity. Eye 2007;21:1-3.

14. White PF, Way WL, Trevor AJ. Ketamine--its pharmacology and therapeutic uses. Anesthesiology 1982;56:119-36. [CrossRef]

15. Reich DL, Silvay G. Ketamine: an update on the first twenty-five years of clinical experience. Can J Anaesth 1989;36:186-97 [CrossRef]

16. Green SM, Roback MG, Krauss B, Brown L, McGlone RG, Agrawal D, et al; Emergency Department Ketamine Meta-Analysis Study Group. Predictors of airway and respiratory adverse events with ketamine sedation in the emergency department: an individual-patient data meta-analysis of 8,282 children. Ann Emerg Med 2009;54:158-68.e1-4. [CrossRef]

17. Welborn LG, Greenspun JC. Anesthesia and apnea. Perioperative considerations in the former preterm infant. Pediatr Clin North Am 1994;41:181-98. [CrossRef]

18. Demirel N, Bas AY, Kavurt S, Celik IH, Yucel H, Turkbay D, et al. Remifentanil analgesia during laser treatment for retinopathy of prematurity: a practical approach in neonatal intensive care unit. Am J Perinatol 2014;31:983-6. [CrossRef]

19. Ulgey A, Güneş I, Bayram A, Aksu R, Biçer C, Uğur F, et al. Decreasing the need for mechanical ventilation after surgery for retinopathy of prematurity: sedoanalgesia vs. general anesthesia. Turk J Med Sci 2015;45:1292-9 [CrossRef]

20. Shah VA, Yeo CL, Ling YL, Ho LY. Incidence, risk factors of retinopathy of prematurity among very low birth weight infants in Singapore. Ann Acad Med Singapore 2005;34:169-78.

21. Walther-Larsen S, Rasmussen LS. The former preterm infant and risk of post-operative apnoea: recommendations for management. Acta Anaesthesiol Scand 2006;50:888-93. [CrossRef]

22. Yavaşcaoğlu B, Kaya FN, Özcan B, Yılmaz C, Töre G, Ata F, et al. The Practice of General Anesthesia for the Laser Therapy of Neonates with Retinopahty of Prematurity: A Retrospective Analysis. Uludağ Üniversitesi Tip Fakültesi Derg 2007;33:65-9. 
ORİJINAL ÇALIŞMA - ÖZET

Prematüre retinopatisinde lazer fotokoagülasyon sırasında sedoanaljezi yöntemi: İntraoperatif komplikasyonlar ve erken postoperatif takip

Dr. Sedat Saylan, ${ }^{1}$ Dr. Ali Akdoğan, ${ }^{1}$ Dr. Şebnem Kader, ${ }^{2}$ Dr. Ersagun Tuğcugil,, ${ }^{1}$ Dr. Ahmet Beşir, ${ }^{1}$ Dr. Mehmet Kola, ${ }^{3}$ Dr. Yakup Aslan ${ }^{2}$

${ }^{1}$ Karadeniz Teknik Üniversitesi Tıp Fakültesi, Anesteziyoloji ve Reanimasyon Anabilim Dalı, Trabzon

${ }^{2}$ Karadeniz Teknik Üniversitesi Tıp Fakültesi, Yenidoğan Bilim Dalı, Trabzon

${ }^{3}$ Karadeniz Teknik Üniversitesi Tıp Fakültesi, Göz Hastalıkları Anabilim Dalı, Trabzon

AMAÇ: Erken teşhis ve tedavi edilmezse retinal dekolmana ve körlüğe neden olabilen prematüre retinopatisinin (PR) tedavisinde uygulanan laser fotokoagülasyon tedavisi (LFT) cerrahi bir prosedürdür. LFT'de uygulanan anestezi yöntemi sedo-analjeziden genel anesteziye, havayolu yönetimi spontan ventilasyondan endotrakeal entübasyona kadar değişkenlik göstermektedir. Bu çalışma ile kırılgan popülasyon olan prematüre bebeklerde entübasyon ve mekanik ventilasyondan kaçınarak sedoanaljezi uygulamalarımızın etkinliğini, bu anestezi yöntemini intraoperatif ve postoperatif komplikasyonlar açısından değerlendirmeyi amaçladık.

GEREÇ VE YÖNTEM: Bu geriye dönük çalışma, PR nedeniyle anestezi altında lazer fotokoagülasyon uygulanmış 89 olguyu içermektedir. Hastaların demografik özellikleri, preoperatif risk faktörleri, anestezi tekniği, özellikle havayolu yönetimi, cerrahi süresince ventilasyon durumundaki değişiklikler, intraoperatif komplikasyonlar, postoperatif komplikasyonlar, yoğun bakım takip süreci kayedildi ve istatistiksel olarak analiz edildi.

BULGULAR: Lazer fotokoagülasyon uygulanan 89 hastadan ikisi entübe halde takip edildiği için çalışma dışı bırakıldı. İntraoperatif komplikasyon gelişmesi sonucu maske ventilasyon uygulanan hasta sayısı I2 (\%।3.8) idi. Ortalama operasyon süresi 36.2 2 I0.I dakika idi. Hastaların \%86.2'sinde $(n=75)$ cerrahi işlem spontan ventilasyon korunarak sedoanaljezi ile tamamlanandı.

TARTIŞMA: Erken tanı ve acil tedavi gerektiren PR hastalarının cerrahi müdahalesi sırasında sedoanaljezi uygulaması intraoperatif ve postoperatif komplikasyonları azaltabilir. Anestezi yöntemi olarak sedoanaljezi yaklaşımının spontan ventilasyonu koruyarak etkili bir alternatif yöntem olarak uygulanabileceği kanısındayız.

Anahtar sözcükler: Lazer fotokoagülasyon; prematüre retinopatisi; sedoanaljezi.

Ulus Travma Acil Cerrahi Derg 2020;26(5):754-759 doi: 10.14744/tjtes.2020.62378 